\title{
PHYSICAL EDUCATION AND SCHOOL SPORT OF THE GERMAN MINORITY IN POLAND IN THE INTERHAR PERIOD OF THE 2OTH CENTURY
}

\author{
Tomasz Jurek \\ University School of Physical Education in Poznań, Faculty of Physical Culture in Gorzów Wielkopolski, Poland \\ Address for coprespondence: \\ Tomasz Jurek \\ Faculty of Physical Culture \\ Estkowskiego 13, 66-400 Gorzów Wlkp., Poland \\ E-mail: t.jurek@awf-gorzow.edu.pl
}

\begin{abstract}
Anstract In the interwar period of the $20^{\text {th }}$ century, $30 \%$ of the total population of Poland was comprised of national minorities. Among them, the German minority of 740 thousand people played a very prominent role. The Germans lived mainly in the western parts of Poland: Pomeranian, Poznań and Silesian voivodeships, as well as in the district of Łódź. The German community was wealthy and influential thanks to the economic traditions and support provided by the German state. In order to stop the process of polonization, the Germans established and developed numerous forms of economic, cultural and social activity. They were very active in the area of physical culture. Their activities included taking great care of the development of physical education and sport in German schools at both primary and secondary education level. Physical education classes were taught and school sports competitions were organized. Physical education was one of the most popular school subjects and was intended to preserve the "German spirit" among pupils. The majority of German schools had a curriculum in place that included two hours of physical education per week and some of them even four hours of PE classes per week. The best teaching staff and sports facilities were to be found in private schools, especially secondary schools, where physical education and school sports enjoyed a very prominent status.
\end{abstract}

Key Words German minority in Poland, school sport, physical education of national minorities

\section{Introduction}

There have been few papers to date describing the evolution and development of German physical culture in Poland between 1918 and 1939. Little attention has been paid to this issue either in Poland or in Germany. Only after the political breakthrough in Poland in 1989 and the reunification of Germany in the early 1990s, there were some studies or papers on the German minority living within the borders of the Second Polish Republic published. In the interwar period, the German community in Poland actively participated in numerous cultural activities as well as in physical education and sports. During this period, the German Gymnastics Association in Poland (Deutsche Turnerschaft in Polen) was active bringing together gymnastics organizations (Turnvereine) and being the largest sports organization of the German population in Poland. The only paper that fully presents the 
evolution of the gymnastics movement, physical education and sport among the Germans living in Poland until 1939 is a monograph written by Tomasz Jurek entitled "Kultura fizyczna mniejszości niemieckiej w Polsce w latach 1918-1939". The paper discusses the activity of the Germans in the field of broadly defined physical culture in the Second Polish Republic. It is, therefore, worth presenting various aspects of German activity in the social and cultural sphere, including physical education and sport in German schooling and school education in Poland up to the year 1939 (Jurek, 2002).

\section{German minority in Poland in the years 1918-1939}

The third part of the population of the independent Polish state in the period 1918 to 1939 were national minorities. Consequently, every third citizen of the Second Polish Republic was of a nationality different than Polish. The most influential were the Ukrainian, Jewish and German minorities, reflecting their considerable numbers and their economic situation. Furthermore, the Germans living in Poland received extensive support from the German state (the Weimar Republic and later the Third Reich). After the end of World War I, the German population reached 2.2 million people, and then their numbers gradually dwindled. The census conducted in 1931 revealed that Poland was inhabited by 741 thousand people of German nationality, constituting $2.3 \%$ of the total population of the country. Most Germans lived in three western provinces or voivodeships: Poznań, Silesian and Pomeranian voivodeships, while the center of the German presence in Poland was the town of Bielsko-Biała, where Germans constituted $64 \%$ of the entire town's population. Detailed data concerning the population in the relevant provinces in the years 1921-1931 is presented in Table 1.

Table 1. German population in the Second Polish Republic based on the results of Polish censuses of 1921 and 1931

\begin{tabular}{lcccc}
\hline \multirow{2}{*}{ Province/Voivodeship } & Number of Germans (in thousands) & \multicolumn{2}{c}{ Percentage of the total population of Poland } \\
\cline { 2 - 5 } & 1921 & 1931 & 1921 & 1931 \\
\hline Poznań & 327.2 & 193.1 & 16.5 & 9.2 \\
Silesia & 292.9 & 90.6 & 27.5 & 7.0 \\
Pomerania & 175.4 & 105.4 & 18.5 & 9.8 \\
Łódź & 103.5 & 155.3 & 4.6 & 5.9 \\
Warsaw & 47.4 & 73.6 & 2.2 & 2.9 \\
Volhynia & 25.0 & 46.9 & 1.8 & 2.3 \\
Stanyslaviv & 15.0 & 16.7 & 1.3 & 1.1 \\
Lviv & 12.4 & 12.0 & 0.5 & 0.4 \\
Lublin & 10.9 & 15.9 & 0.5 & 0.6 \\
Kraków & 9.6 & 8.9 & 0.5 & 0.4 \\
Rest & 39.9 & 22.6 & 0.3 & 0.2 \\
\hline Total & $1,059.2$ & 741.1 & 3.8 & 2.3 \\
\hline
\end{tabular}

Source: Mały Rocznik Statystyczny 1938 (1939), pp. 22-23; Statystyka Polski. Pierwszy Powszechny Spis Ludności Rzeczypospolitej Polskiej z dnia 30 września 1921 r. (1927); Statystyka Polski. Drugi Powszechny Spis Ludności z dnia 9 grudnia 1931 r. (1938).

\section{German minority's schooling and school education}

Under the Treaty on the Protection of National Minorities, Poland was obliged to provide its citizens with educational opportunities available in the mother tongue of the children subject to compulsory education. That law, in conjunction with the national legislation, made it possible for national minorities to establish and operate their own 
schools with the language of instruction other than Polish. The German communities made extensive use of that opportunity, placing a high priority on universal, general and vocational education. That was largely facilitated by the material support received from Germany, as education was seen as one of the strongholds of Germanness and a kind of defense against denationalization. The largest group of German educational institutions were common schools with German as the language of instruction, totaling 1,560 in the school year of 1921/1922. In Poland, some 1,908 teachers worked with a large group of 106,849 students. As the number of Germans in the Second Republic of Poland decreased, the number of schools also dropped, reaching 777 schools attended by 63,158 pupils in the school year of 1929/1930, and 577 schools with 54,693 pupils in 1938/1939. Common schools were divided into public (managed by the educational authorities) and private (established and funded by the German minority). In the second half of the 1920s, a more widespread action of itinerant teaching (the so-called "Wanderschulen") emerged, drawing on the principles of "Mutterschulen", i.e. teaching conducted at students' homes or anywhere, in particular in rural areas, where German schools were in short supply. A group of "itinerant teachers" was formed i.e. teachers who often travelled tens of kilometers between German homes and housing estates. In 1928, a total of 1,336 towns with over 11,000 students and 16 teachers across the country were involved in this form of illegal teaching. A good example of how significantly the German schooling system was subsidized is the secondary school located in Leszno, whose budget in the school year of $1933 / 34$ amounted to 140,000 zlotys, including 93,000 zlotys provided by the Deutscher Schulverein. At the same time, about 112-116 thousand zlotys per annum was allocated to the whole educational system in the town (Komolka, 1984).

In the school year of 1937/1938, the other types of schools with German as the language of instruction included 14 secondary schools (including 11 private ones), 13 upper secondary schools (including 11 private ones) and 7 vocational schools attended by 3,086 pupils in total. The school statistics also included 52 German kindergartens (including 51 private ones) with 1,767 children attending (Iwanicki, 1984; Hauser, 1998, pp. 197-199; Mauersberger, 1968). The German School Association (Deutscher Schulverein - DSV) had its own branches operating within the schools and being in charge of all the activities carried out by the educational institutions. DSV with its headquarters in Bydgoszcz had 2,000 members and was chaired by K. Graebe and O. Schönbeck (Dąbrowski, 1978). Teachers working in German schools were affiliated with the National Association of Teachers in Poland (Landesverband deutscher Lehrer und Lehrerinnen in Polen - LVdLLP) founded in 1920. The LVdLLP, with its headquarters in Bydgoszcz, was chaired by Paul Jendricke. Jendricke had collected interesting personal stories and recollections of teachers working in German schools in Poland, stored in the J.G. Herder Institute in Marburg (Jurek, 1999).

\section{Physical education classes in the curpiculum of Gepman schools}

The Germans placed great value on teaching and educating children and youths deeming this activity to be one of the pillars of patriotic effort. Physical education was an important part of the curricula of primary and secondary schools. This type of attitude stemmed from the rich nineteenth-century tradition of German education in which physical education played an important role. Moreover, in many German communities, physical education and school sport were perceived as paramilitary exercises, indispensable for every student who was to be enrolled into the army in the future. However, it was not the Polish army that was meant but the German army, which was significantly weakened as a result of World War I (Jurek, 2002).German schools pursued a similar curriculum as the Polish educational institutions. The only differences were German language classes and teaching about Germany conducted as part of German language, history and geography classes. The teachers tried to impart to their 
students as much knowledge and information as possible about the German tradition. That also included physical education where they followed the teachings of Frederick Ludwig Jahn, a German gymnastics educator and founder of German gymnastics movement. Polish-German primary schools with German as the language of instruction had in place the following weekly timetable for physical exercise, often called gymnastics: grade one -0.5 hours, grades two to six -1 hour. The total weekly school workload for pupils at that time was as follows: grade one -14 hours of school a week, grade two - 17 hours, grades three and four -24 hours, grades five and six -30 hours. Some schools that had very good housing conditions, e.g. those located in Poznań, offered as many as 4 hours of physical education classes per week (Archive of New Files). The number of hours of physical education in common schools with German as the language of instruction is shown in Table 2.

Table 2. Physical education in the curriculum of German primary schools in Poland in 1936

\begin{tabular}{|c|c|c|c|c|c|c|c|c|}
\hline \multirow{2}{*}{ Type of school } & \multirow{2}{*}{ School subject } & \multicolumn{7}{|c|}{ Grade } \\
\hline & & 1 & 2 & 3 & 4 & 5 & 6 & 7 \\
\hline \multirow{2}{*}{6 teachers and more } & $\mathrm{PE}$ & 2 & 2 & 2 & 2 & 2 & 2 & 2 \\
\hline & total & 18 & 21 & 27 & 28 & 30 & 30 & 30 \\
\hline \multirow{2}{*}{6 teachers } & $\mathrm{PE}$ & 2 & 2 & 2 & 2 & \multicolumn{3}{|c|}{2 for boys +2 for girls } \\
\hline & total & 18 & 21 & 27 & 28 & 30 & 30 & 30 \\
\hline \multirow{2}{*}{5 teachers } & $\mathrm{PE}$ & 1 & 1 & \multicolumn{2}{|c|}{2} & \multicolumn{3}{|c|}{2 for boys +2 for girls } \\
\hline & total & 16 & 18 & 27 & 28 & 30 & 30 & 30 \\
\hline \multirow{2}{*}{4 teachers } & $\mathrm{PE}$ & 1 & 1 & \multicolumn{2}{|c|}{2} & \multicolumn{2}{|c|}{1 for boys +1 for girls } & - \\
\hline & total & 15 & 18 & 26 & 26 & 30 & 30 & - \\
\hline \multirow{2}{*}{3 teachers } & $\mathrm{PE}$ & 1 & 1 & \multicolumn{2}{|c|}{1} & \multicolumn{2}{|c|}{1} & - \\
\hline & total & 15 & 16 & 23 & 24 & 30 & 30 & - \\
\hline \multirow{2}{*}{2 teachers } & $P E$ & $1+$ singing & $1+$ singing & \multicolumn{2}{|c|}{1} & - & - & - \\
\hline & total & 12 & 13 & 20 & 22 & - & - & - \\
\hline \multirow{2}{*}{1 teacher } & $\mathrm{PE}$ & $1+$ singing & $1+$ singing & $1+$ singing & $1+$ singing & - & - & - \\
\hline & total & 15 & 15 & 19 & 19 & - & - & - \\
\hline
\end{tabular}

Source: Deutsche Schulzeitung in Polen, no. 8/9, pp. 133-134.

Secondary schools had a different timetable in place. Those with German as the language of instruction had two physical education classes for a total of 30 hours of school per week. In private secondary schools, it was possible to increase the number of physical education classes from two to three and afterwards up to four hours per week. In 1929, secondary schools in Poznań launched a scheme aimed at increasing the total number of hours of physical education by one third so that they would constitute $10 \%$ of all school hours. An equally comprehensive curriculum was followed by the German secondary school (Goethe Gymnasium) in Grudziądz, where four hours of physical education per week were introduced, which accounted for $13 \%$ of all school hours (Deutsche Schulzeitung in Polen, 1932).

\section{Physical education curpiculum and its delivery}

Physical education curriculum in German schools was executed in different ways, depending on the facilities in place and the teaching staff working there. The best conditions in this respect were offered by the largest German schools in major cities, especially in such places as Bielsko, Bydgoszcz, Chorzów, Grudziądz, Katowice, Leszno, 
Łódź and Poznań. Those schools were either housed in their own premises or in rented buildings. The secondary school (Goethe Gymnasium) in Grudziądz was unique in this respect as it had a modern gym measuring $32 \mathrm{~m}$ in length and $14 \mathrm{~m}$ in width. German secondary schools in Poznań also had their own gyms of $22 \mathrm{~m} \times 10 \mathrm{~m}$ in size. However, the conditions for teaching physical education classes were hard across the country. The headmasters of German schools entrusted teaching of physical education to teachers who had the necessary experience that they had gained in gymnastics societies or associations (Deutsche Turnerschaft). By way of example, in the school year of 1924/1925 the secondary school in Bielsko offered physical education classes that were taught by six different teachers, mainly linguistic scholars, who were also teachers of other subjects such as chemistry, history, physics, Greek, German, Polish, Latin and life sciences. A similar situation was also observed in other German secondary schools, where qualified physical education teachers were not easily available. Five years later, three physical education teachers worked in the same school in Bielsko (Jahresbericht der Direktion des Staatsgymnasiums mit deutscher Unterrichtssprache in Bielitz fur das Schuljahr 1924/1925, p. 22). All in all, there were nine trained physical education teachers working in Poznań, Greater Poland and Łódź voivodeships, who taught mainly in German secondary schools, considered to be "a stronghold of German education and national activity". The group included the following teachers: Maria Correm, Alfons Stempel (Goethe Gymnasium in Grudziądz), Gerhard Drage (Schiller Gymnasium in Poznań), H. Schmidt (Kant Gymnasium in Leszno), Wilhelm Ruppenthal (private secondary school in Łódź), Alfred Coppe, Ruth Scheerschmidt (private secondary school in Bydgoszcz), A. Fiedler (private secondary school in Pabianice), Ruth Bicherich (secondary school in Poznań) (Federal Archives in Berlin, Deutsche Stiftung, file no. 447, p. 346).

The LVdLLP press service "Deutsche Schulzeitung in Polen" played an important role (Deutsche Schulzeitung in Polen, 1926) in the promotion of physical education in German schools. Physical education curricula and advice on PE methodology were published in the journal. It also featured articles on the teaching methods for gymnastics, athletics, team sports games and water and winter sports. Training materials were also published there, e.g. "On the Importance of Gymnastics in the Life of a Young Person". A special supplement on methodology of gymnastics was also published in the journal. It focused on physical education conducted in a variety of conditions, e.g. in the winter period. The journal published detailed sets of exercises, PE lesson scenarios as well as teaching materials on the modern system of physical education in German schooling system under the common title "Die Körperschule Geschichtliches und Methodisches". In their articles, the authors emphasized the German patriotism necessary for physical education classes and the texts were often published under the collective title of Für unsere Schularbeit (Deutsche Schulzeitung in Polen, 1935).

Physical education classes depended largely on the tradition of the school and its location, as evidenced by the annual report of the secondary school in Bielsko:

As long as the weather permitted, the square in front of the school was used, as track and field disciplines could only be practiced in the open air. The track and field activities included only short and long distance running, long jump, high jump, triple jump, pole vault, discus and hand grenade throw, shot put and ball throw. The square also hosted outdoor games played during gymnastics classes and during designated afternoon sessions. The games included basketball, volleyball, the game of palant, Czech handball and volleyball. In addition, young people were given the opportunity to play various games and participate in fun activities. The school also offered skis, ice skates and sledges for rent to their pupils during the winter period (Jahresbericht der Direktion des Staatsgymnasiums mit deutscher Unterrichtssprache in Bielitz fur das Schuljahr 1928/1929, Bielitz, pp. 22-23). 
Physical education classes were taught in a similar way in other German schools, in which games and fun activities were mainly held, often combined with singing classes and trips to the surrounding area. After gymnastics classes, which dominated in the 1920s, PE classes involving sporting games started to grow in popularity in the period that followed. The schools often arranged trips to the countryside to visit German farming estates, especially in Upper Silesia and in Bydgoszcz, Łódź and Poznań. School children aged 14 to 19 were also sent to Germany to spend their holidays. The trips to Germany were co-organized by the German Foundation (Deutsche Stiftung) (Posener Tageblatt, 1925; Federal Archives [Bundesarchiv Berlin], Deutsche Stiftung, file no. 447, p. 364).

Considerable emphasis was placed in German secondary schools on the organization of numerous sporting events with local pupils (school championships) and visitors (inter-school competitions) taking part. The biggest school competitions of this type, usually held around the end of the school year, were organized by German secondary schools in Bielsko, Grudziądz and Poznań. As many as half a thousand people participated in such sports competitions. In April 1934, the secondary school in Grudziądz was the center of preparations for the German sports festival called Ostlandturnfest in Gdańsk. German athletes from such places as Bydgoszcz, Chojnice, Szamocin, Tczew, Toruń and Tuchola participated in the preparations. The event was organized by a teacher from this secondary school, Alfons Stempel (National Archives [Archiwum Państwowe Bydgoszcz], Urząd Wojewódzki Pomorski, file no. 4604, p. 127).

The development of physical education and German school sport was not without its difficulties or problems. One of them was the restriction imposed by the Polish authorities on the participation of pupils under 14 years of age in sporting activities. However, German schools did not attach as much importance to this ban as the Polish schools and tried to evade it. They tolerated the participation of their pupils in the activities of German sports clubs and gymnastics associations. Another serious problem was the attempts of the pupils to obtain the Third Reich Sports Badge, which was forbidden to be worn on the school premises. Eventually, in April 1937, the young people and teachers from German secondary schools refrained from obtaining those badges. The Polish authorities were concerned about the involvement of teachers and school management of German schools in the German athletic movement in Poland and restricted the participation of teachers and pupils in sporting competitions (Federal Archives [Bundesarchiv Berlin], Deutsche Stiftung, file no. 447, pp. 251, 301).

\section{College and university sport}

Students studying at Polish universities were also interested in sport. They were members of the Association of Student Societies in Poland (Verband der Vereine der Hochschüler Polens - VVHP), which was established in 1925. Students from Poznań, belonging to the Society of German Students (Der Verein Deutscher Hochschüler VDH), a member of the VVHP, were very active in this area. In summer, they practiced running and track and field jumps as well as shot put and javelin throw. In winter, they made use of the premises of the Schiller secondary school, where they practiced gymnastics. Fencing and rowing groups were also formed. Rowing was practiced in two clubs, i.e. "Germania" and "Neptun". The most important test for the sporting skills of German students were the unofficial national university championships, held among others in Katowice and Łódź. The students from Poznań were among the best and achieved excellent results when confronted with representatives of other cities. According to one of the participants of the competition G. Meissner, the leading athletes demonstrated a high level of sportsmanship, obtaining very good individual results: 11.4 seconds for a $100 \mathrm{~m}$ sprint; $23.0 \mathrm{~s}$ for a $200 \mathrm{~m}$ sprint; $52.0 \mathrm{~s}$ for a $400 \mathrm{~m}$ sprint; 17 minutes for a $5 \mathrm{~km}$ run; $11.80 \mathrm{~m}$ for shot put; $70 \mathrm{~m}$ for javelin throw; $6.60 \mathrm{~m}$ for long jump (Bierschenk, 1988, pp. 96-98). 


\section{Conclusions}

Taking stock of the accomplishments and achievements of physical education and sport in German schooling system in Poland in the period of 1918 to 1939, it should be concluded that the German minority in Poland as well as the system of material support provided by Germany have significantly helped to boost the development of this area of activity. Patriotism and commitment to the country of origin, i.e. Germany, were strongly emphasized during the physical education classes in order to avoid the polonization of the young generation of Germans in Poland. As a result, young people did not yield to Polish influence and remained within the sphere of influence of the German national tradition.

\section{References}

Archive of New Files [Archiwum Akt Nowych Warszawa]. Ministerstwo Wyznań Religijnych i Oświecenia Publicznego, 162, p. 239; 193, pp. 7, 105, 208-210.

Bierschenk, T. (1988). Der Vereine Deutscher Hochschüler in Polen 1922-1939. Hannover.

Dąrowski, R. (1978). Życie kulturalno-oświatowe mniejszości niemieckiej w Polsce w dwudziestoleciu międzywojennym (1918-1939). Zeszyty Naukowe Wyższej Szkoły Pedagogicznej w Szczecinie, 23, 204.

Deutsche Schulzeitung in Polen 19/20 (1926). Festnummer zur 5. Verbandstagung des LVdLLP am 3-5 Juli 1926 in Posen, pp. 228-230.

Deutsche Schulzeitung in Polen 19/20 (1932).

Deutsche Schulzeitung in Polen, 3 (1935).

Deutsche Schulzeitung in Polen, 8/9.

Federal Archives [Bundesarchiv Berlin], Deutsche Stiftung, file no. 447.

Hauser, P. (1998). Mniejszość niemiecka na Pomorzu w okresie międzywojennym. Poznań.

Iwanicki, M. (1984). Legalne i nielegalne szkolnictwo niemieckie w Polsce w okresie międzywojennym. In: A. Czubiński (ed.), Rola mniejszości niemieckiej w rozwoju stosunków politycznych w Europie 1918-1945 (pp. 374-375). Poznań.

Jahresbericht der Direktion des Staatsgymnasiums mit deutscher Unterrichtssprache in Bielitz fur das Schuljahr 1924/1925 (1925). Bielitz.

Jahresbericht der Direktion des Staatsgymnasiums mit deutscher Unterrichtssprache in Bielitz fur das Schuljahr 1928/1929 (1929). Bielitz.

Jurek, T. (1999). Rola Instytutu J.G. Herdera w Marburgu w badaniach regionalnych. Nadwarciański Rocznik Historyczno-Archiwalny, 6/2, 177-180.

Jurek, T. (2002). Kultura fizyczna mniejszości niemieckiej w Polsce w latach 1918-1939. Gorzów Wlkp.-Poznań: Polskie Towarzystwo Naukowe Kultury Fizycznej Sekcja Historii.

Komolka, M. (1984). Szkolnictwo dla mniejszości niemieckiej w Lesznie w okresie międzywojennym. In: A. Czubiński (ed.), Rola mniejszości niemieckiej w rozwoju stosunków politycznych w Europie 1918-1945 (pp. 391-392). Poznań.

Mały Rocznik Statystyczny 1938 (1939). Warszawa.

Mauersberger, S. (1968). Szkolnictwo powszechne dla mniejszości narodowych w Polsce w latach 1918-1939. Wrocław.

National Archives [Archiwum Państwowe Bydgoszcz]. Urząd Wojewódzki Pomorski, file no. 4604.

Posener Tageblatt (1925). 154.

Statystyka Polski. Drugi Powszechny Spis Ludności z dnia 9 grudnia 1931 r. (1938). Warszawa.

Statystyka Polski. Pierwszy Powszechny Spis Ludności Rzeczypospolitej Polskiej z dnia 30 września 1921 r. (1927). Warszawa.

Cite this article aS: Jurek, T. (2020). Physical Education and School Sport of the German Minority in Poland in the Interwar Period of the 20th Century. Central European Journal of Sport Sciences and Medicine, 2 (30), 25-31. DOI: 10.18276/cej.2020.2-03. 